\title{
Research on the Construction of "15-Minute" Cities under the Health Impact Assessment
}

Hao Zhang,North China University of Technology,China

Jing Li,North China University of Technology,China

\begin{abstract}
China's urban development has entered a new stage of development. With the emergence of urban development needs and problems in the post-epidemic period,health impact assessment is an important topic for future urban development.There are a large number of small towns in China, the current level of construction and development is uneven, the level of public service facilities is uneven, and there is a strong internal need for renewal and transformation. At the same time,small towns are important construction sites for building a walking and healthy "15-minute" cities due to their small urban scale.This article takes Quyang County, Hebei Province as an example,through multi-source data collection such as questionnaire surveys,big data collection, individual behavior logs, combined with data on the behavior characteristics of small towns residents, the distribution of public service facilities, and residents' individual behavioral needs, scientifically evaluate the current situation of the layout of related facilities in the city, and then put forward targeted construction and optimization measures. From the travel range of residents of different ages, the "15-minute" cities are delineated, and from the perspective of public health, the three aspects of healthy framework - transportation system, healthy patches-public service facilities, healthy substrate-leisure space, construct a Specific "15-minute" citiy.
\end{abstract}

\section{Keywords}

Public service facilities configuration, Health impact assessment, "15-minute" cities

\section{Background}

\subsection{The Significance of Improving the Public Health Level of Small Towns}

Health is the foundation of human survival,and the demand for health from the country to the individual is being paid more and more attention. With the continuous advancement of urbanization,the development speed of many developing countries is accelerating.Compared with developed countries, they lack a gradual industrial development and population transfer stage ${ }^{[1]}$, so they are also faced with the quality of construction, the quality of life of residents, and the level of social management. The phenomenon of low-level,large-scale "urban disease" is spreading day by day.Urban planning has also received increasing attention as a means of improving public health.At the same time, with the outbreak of the new crown epidemic in 2020,it has also sounded the alarm for urban public health.At present, "public health" has also become a topic of great concern to the public.Planning the academic circles have carried out in-depth thinking on the construction of human settlements and public health.As the link between urban and rural areas,small towns gather a large number of people and are also important gathering places for the development of important industries in the future.Improving the high-quality development of small towns and improving public health will become important basic points for measuring the construction of small towns. 


\subsection{The Necessity of Planning the Construction of Living Circles in Small Towns}

As an important measure to balance the allocation of space resources and maintain the fairness of space and the quality of life, in 2018,the Ministry of Housing and Urban-Rural Development of China issued the "Urban Residential District Planning and Design Standards" that proposed the concept of living circle,which also caused domestic scholars to study The boom, the life circle emphasizes the relationship between the allocation of space facilities and the needs of residents from the perspective of residents' living space. ${ }^{[2]}$ As an important unit of urban public health management and control,small towns have a smaller living scale than large cities and a slower lifestyle of residents. In this epidemic,they face insufficient medical resources,incomplete supporting facilities, and risk response coefficients.Lower practical problems,combined with the health problems faced by small towns and urban renewal,delimiting the life circle of small towns has become an important issue that needs to be solved urgently in the development of urbanization in my country.

\subsection{Research Overview of the "15-minute" cities}

From the perspective of the development of foreign,in 1943, scholar W.H.Burt proposed the concept of "home rage", which was the germination of the idea of discussing the activity space of residents with the family as the center ${ }^{[3]}$.The proposal of "Life Circle" can be traced back to Japan,and its concept comes from Japan's "Rural Living Environment Improvement Plan",which pays more attention to transforming and reshaping communities with human scale and experience,and enhancing urban and rural vitality ${ }^{[4]}$.In 1969, the Japanese Autonomous Ministry launched the "wide-area city,town and village circle" plan,and the Ministry of Construction and the Land and Resources Agency respectively proposed the concepts of "local life circle" and "fixed residence circle" [5].From the perspective of the research scale of the life circle, it involves the study of countries, regions and settlements. Research in Japan mostly focuses on the national and regional levels, mainly focusing on the optimal allocation of urban and rural resources and solving the problems of uneven urban spatial development.Germany's land planning proposed the planning concept of building a living circle around the center to narrow the gap between urban and rural living environments ${ }^{[6]}$.The concept of living circles is also mentioned in the "National Comprehensive Land Development Plan" of South Korea ${ }^{[7]}$. Their research mainly focuses on the scale of residential areas,and proposes the allocation of public service facilities according to the level of living circles,emphasizing that the service facilities are within walking distance ${ }^{[8]}$.From the perspective of the research content of the living circle,Japanese scholars have done more research.Takeshi Koide,Yoshio Arai,Masa Fujii ${ }^{[9]}$ etc.inspected the living circle based on residents' shopping activities,commuting rate,etc; Yamashita Katsuhiko took the connection between commuting and medical facilities of Iwate County residents as the research focus,combined with the current development status of Iwate County, and rationally divided the living circle of the area ${ }^{[10]}$.The "Melbourne 2050 Master Plan" pointed out that from the perspective of the city's master plan,we should create a "20-minute living circle",create high-density land in the city,create a healthy living circle, rationally lay out public service facilities, and improve travel methods ${ }^{[11]}$,Mainly include: walking and cycling traffic,public facilities and open space,efficient services,etc.In order to implement public health management,Australia has set up public health community units.In addition to the corresponding hardware facilities,each health unit also provides relevant virus detection and medical freezer ${ }^{[12]}$.

In the early 1990s,china's urban and rural planning circles introduced the concept of "life circle" planning. The spatial scale of its research and practice covers multiple levels such as regions, cities, and communities,covering housing and commuting,public facility allocation,recreation and leisure.Behavior and many other directions.Chen Qinghui ${ }^{[13]}$ proposed the division of home-centered core life circle,community-centered basic life circle, and city-centered urban life circle.Yuan Jiadong ${ }^{[14]}$ proposed the basic life circle,basic life circle, With concepts such as opportunity life circle,Chai Yanwei ${ }^{[15]}$ constructed a 
hierarchical structure of urban life circle planning centered on "basic life circle-commuter life circleexpanded life circle-cooperative life circle".As scholars start from a humanistic perspective,they try to combine the theory of living circles that pay attention to human behavior, the daily needs of residents, and the living environment with spatial planning to evaluate the quality of urban living environment,Xiong Wei et al. ${ }^{[16]}$ used public space,public service facilities and other factors to evaluate urban environmental suitability.Kang Xiaojuan ${ }^{[17]}$ constructed two types of circles: a basic life circle and a quality life circle.Sun Daosheng ${ }^{[18]}$ and others used GPS data and activity log data to obtain individual behavior data, and proposed the concept of daily life circle.Zhu Chasong ${ }^{[19]}$ et al.used the survey and analysis of residents' travel to understand the frequency of residents' demand, and use this as a basis to construct different levels of living circles for the allocation of public service facilities. However, the current research on the life circle is still in the allocation of urban public facilities and the evaluation of the built environment,and there is a relatively lack of empirical application in planning.Since the outbreak of the new crown epidemic in 2019, it has had a certain impact on the development of cities.Relevant scholars have also explored urban health and living circles. Wang Lan ${ }^{[20]}$ and others pointed out that the planning of future healthy living circles should be combined with disaster prevention. The emergency system proposes to build a life circle for daily health and emergency response to the epidemic.

At present,the concept of life circle is gradually generalized.Research on the application of these concepts is aimed at the city level.The research on the life circle at the small town level is relatively less. Therefore,this article focuses on the level of small towns, from the perspective of the construction of the '15-minute' from the perspective of public health,according to the current urban public facilities configuration and the differences in the actual needs of residents under different spatial forms, delimits the small town '15-minute', and proposes targeted travel in small towns.with a view to a more active and healthy development of small towns in the post-epidemic period.

\section{Research objects and data}

\subsection{Introduction}

The research object is located in Quyang County,Baoding City, Hebei Province. The county's topography is relatively high.The topography is mainly low mountain plains and abundant mountains and water resources.It is China's "land of carvings". The specific research object selected this time is the central urban area of Quyang.The construction land area of the urban area is 37.3 square kilometers. The current roads in the urban area are laid out by the ring road and the longitudinal road in a grid grid. The current green space surrounds the urban area.There is Baijiawan Park in the northwest and the northeast.There is the Jiahe Mountain Forest Park and the Mengliang River Park in the south.The water system landscape dominated by the Mengliang River is scattered throughout the city.In the west of the city, there are the Beiyue Temple and the Xiude Temple Pagoda National Cultural Relics Protection Unit,as shown in Figure 1.Quyang County currently has a population of 350,000 , and the population is constantly intensive.The requirements for the construction level of the city are also correspondingly improved. 


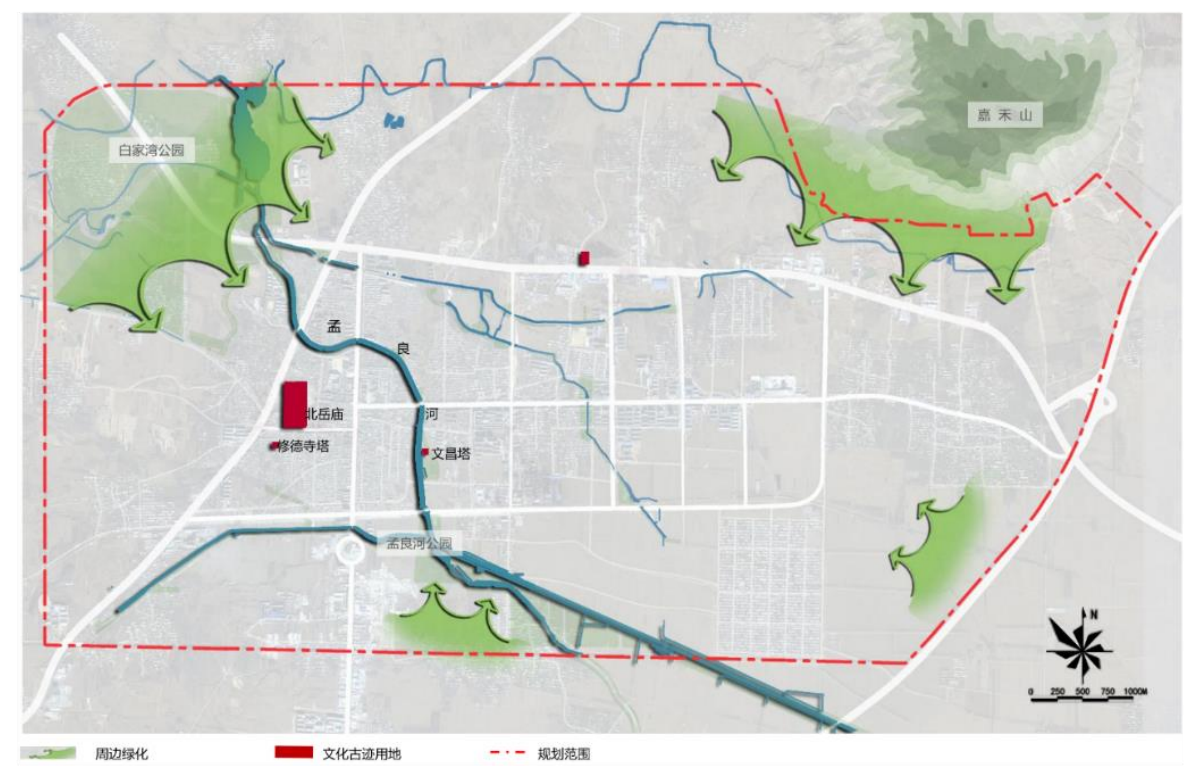

Figure 1.Current landscape analysis.Source: Self-painted.

\subsection{Research methods}

Through questionnaire surveys, individual activity log surveys, heat maps, $\mathrm{POI}$ and other data,we can understand the different behavior characteristics of residents in different urban spatial forms,as well as the cycle and frequency of using different facilities, and screen the establishment of residents' behavior and the spatial elements of the built environment of different cities.A model of time to build a life circle.

\section{Analysis of the spatial status and residents' behavior in small towns}

\subsection{Analysis on the characteristics of urban space}

Taking Quyang County as the research sample,the characteristic spatial form of its central city is divided into three categories: old city, newer city and new city. The scope of the old city is delineated by the historical area,and the newer city is based on the old city. The new urban area is the area for future construction and development, which is not specifically delineated for the time being,as shown in Figure2.

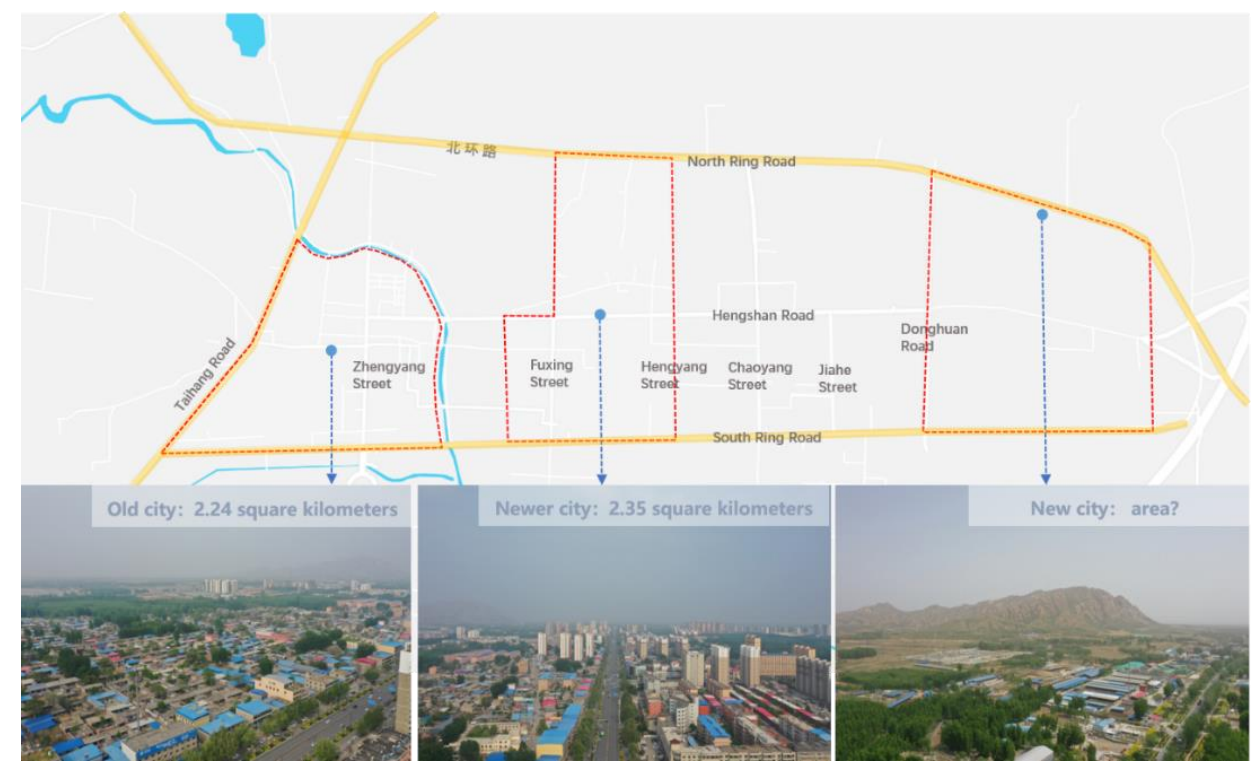

Figure 2.Delineation range and location of different spatial forms.Source: Self-painted. 
The first type of space type is the construction type of the old city. The blocks under the city scale are small and dense.The building construction was mainly before 2008. The construction height is also low.The living population is mainly the elderly.The current infrastructure and openness Space also faces some problems. The second type of space type is the construction type of a relatively new urban area.The blocks under the urban scale are large and long.The construction age is mainly after 2008. The overall construction height of the building is high.The living population is mainly young people.The same status quo basis and Open spaces are also facing some problems. The third type of space type is the construction type of the new urban area.This urban area is to be constructed in 2021. The overall construction should present the characteristics of "small blocks, dense road network, and home roads". This will be used as an experimental sample for key analysis in the future, As shown in Figure 3.

\begin{tabular}{|c|c|c|c|c|c|c|c|c|}
\hline \multirow{4}{*}{$\begin{array}{c}\text { Characte } \\
\text { ristic } \\
\text { spatial } \\
\text { form of } \\
\text { urban } \\
\text { center } \\
\text { (take } \\
\text { Quyang } \\
\text { County } \\
\text { as an } \\
\text { example) }\end{array}$} & $\begin{array}{l}\text { Space } \\
\text { type }\end{array}$ & $\begin{array}{l}\text { Constructio } \\
\mathrm{n} \text { age }\end{array}$ & $\begin{array}{l}\text { Floor } \\
\text { height }\end{array}$ & $\begin{array}{c}\begin{array}{c}\text { Population } \\
\text { characteristics }\end{array} \\
\end{array}$ & Potential advantage & infrastructure & Open space & remarks \\
\hline & $\begin{array}{l}\text { Old } \\
\text { city }\end{array}$ & Before 2008 & $\begin{array}{l}\text { Mainly low- } \\
\text { level }\end{array}$ & $\begin{array}{l}\text { Mainly elderly } \\
\text { Slower pace of life }\end{array}$ & $\begin{array}{l}\text { Features, historical } \\
\text { heritage, complete } \\
\text { facilities, convenient life }\end{array}$ & $\begin{array}{l}\text { Damaged infrastructure } \\
\text { and low qualityPoor } \\
\text { surrounding facilities }\end{array}$ & $\begin{array}{l}\text { Fragmentation and more } \\
\text { green spaces }\end{array}$ & $\begin{array}{c}\text { Key } \\
\text { analysis }\end{array}$ \\
\hline & $\begin{array}{l}\text { Newer } \\
\text { city }\end{array}$ & After 2008 & $\begin{array}{l}\text { Small high- } \\
\text { level main, } \\
\text { high-level } \\
\text { auxiliary }\end{array}$ & $\begin{array}{l}\text { Mainly young } \\
\text { people } \\
\text { Fast pace of life }\end{array}$ & $\begin{array}{l}\text { Clean, well-developed } \\
\text { transportation, } \\
\text { comfortable living }\end{array}$ & $\begin{array}{l}\text { Relatively incomplete } \\
\text { infrastructure needs to be } \\
\text { improved }\end{array}$ & mostly side-by-side & $\begin{array}{c}\text { Key } \\
\text { analysis }\end{array}$ \\
\hline & $\begin{array}{l}\text { New } \\
\text { city }\end{array}$ & After 2021 & $\begin{array}{c}\text { 6-storey } \\
\text { main livable } \\
\text { height }\end{array}$ & All age groups & $\begin{array}{l}\text { High-level green low- } \\
\text { carbon livable new city }\end{array}$ & $\begin{array}{l}\text { Centralized construction, } \\
\text { complete infrastructure }\end{array}$ & $\begin{array}{l}\text { Utilize the natural } \\
\text { environment and current } \\
\text { situation to promote }\end{array}$ & $\begin{array}{c}\text { Future } \\
\text { construction }\end{array}$ \\
\hline \multirow{2}{*}{\multicolumn{9}{|c|}{ 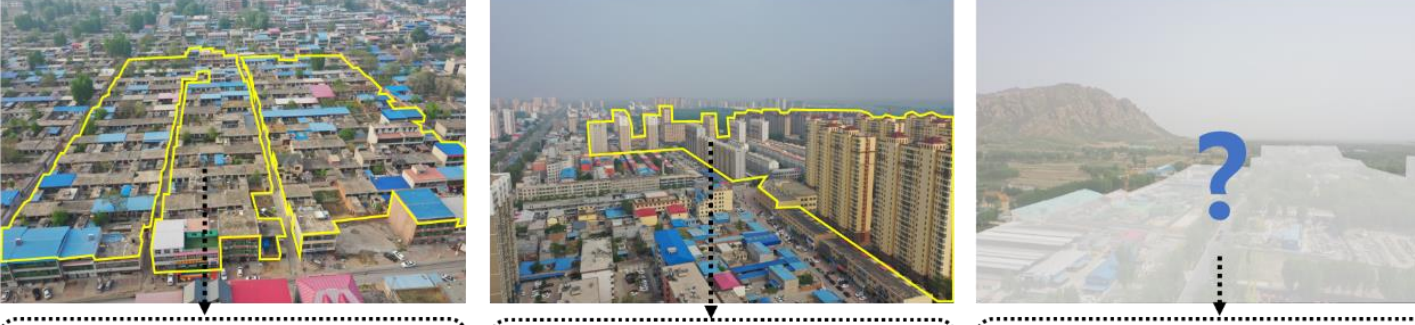 }} \\
\hline & & & & & & & & \\
\hline \multicolumn{4}{|c|}{$\begin{array}{l}\text { old city: } \\
\text { high density ,small and dense blocks are, strong sense of } \\
\text { grouping, shape compact, every } 200 \text { meters a block. }\end{array}$} & \multicolumn{5}{|c|}{$\begin{array}{l}\text { New city: } \\
\text { small dense road network, narrow roads, and the public } \\
\text { service supporting, smooth and continuous trail networ }\end{array}$} \\
\hline
\end{tabular}

Figure 3.Comparison in different spatial forms.Source: Self-painted.

\subsubsection{Analysis on the characteristics of urban space}

By categorizing the current land use types of the entire central city, it is divided into ten major land use types, and through the capture of POI facilities, a total of 2641 facilities are captured, as shown in Figure 4 below.Various POIs include names and longitudes.,Latitude and address, and spatially locate all the facilities, and do nuclear density analysis in GIS,as shown in Figure 5. 


\begin{tabular}{|c|c|c|}
\hline land use classification & Specific classification & Numbers \\
\hline Residential facilities & $\begin{array}{l}\text { Residential districts, apartments, ancillary service } \\
\text { facilities }\end{array}$ & 151 \\
\hline Administrative facilities & $\begin{array}{l}\text { Government agencies, institutions, neighborhood } \\
\text { offices, administrative committees, cooperatives }\end{array}$ & 244 \\
\hline Medical Facilities & Hospitals, health centers, clinics & 92 \\
\hline Public service facilities & $\begin{array}{c}\text { Public toilets, social welfare facilities(Social } \\
\text { Association, Foundation) }\end{array}$ & 25 \\
\hline educational facility & $\begin{array}{c}\text { Elementary and secondary schools, educational } \\
\text { institutions }\end{array}$ & 32 \\
\hline Commercial facilities & $\begin{array}{l}\text { Shopping, commercial plazas, hotels, hotels, shops, } \\
\text { restaurants, supermarkets, convenience stores, } \\
\text { insurance, company certificates,Bank branch }\end{array}$ & 1110 \\
\hline Industrial facility & $\begin{array}{l}\text { First-class industrial land, industrial parks, and } \\
\text { incubation bases }\end{array}$ & 831 \\
\hline Cultural facilities & Library, gymnasium & 10 \\
\hline Road facilities & $\begin{array}{c}\text { Bus station, bus station, gas station, toll station, } \\
\text { high-speed service area }\end{array}$ & 120 \\
\hline Green and square facilities & Land for parks and scenic spots, and land for squares & 26 \\
\hline \multicolumn{3}{|c|}{ total of 2,641 facilities within the central city } \\
\hline
\end{tabular}

Figure 4.Table of different facility types and quantities.Source: Self-painted.

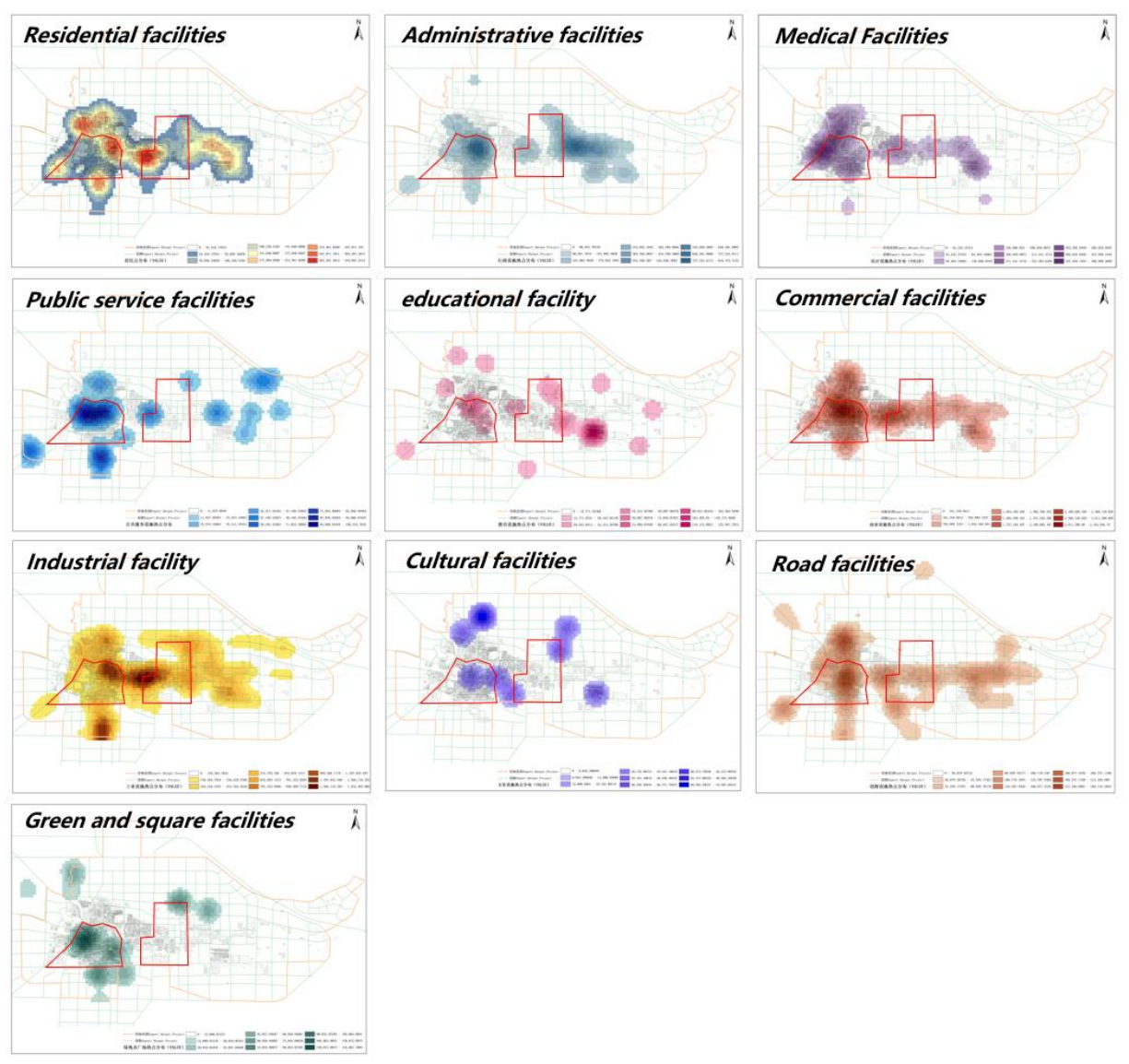

Figure 5.Comparison in different spatial forms.Source: Self-painted.

Among them,the facilities in the old urban area and the newer urban area are extracted,and the proportion of the facilities in the different urban areas in the entire central urban area is measured,and statistics are made into a chart,as shown in Figure 6 below, where the facilities in the old urban area The distribution has a clear contrast with the distribution of facilities in newer urban areas.The distribution numbers of medical facilities,public service facilities and green plaza facilities are the strongest,the distribution of facilities in the old city is more concentrated,and there are more types of facilities. 


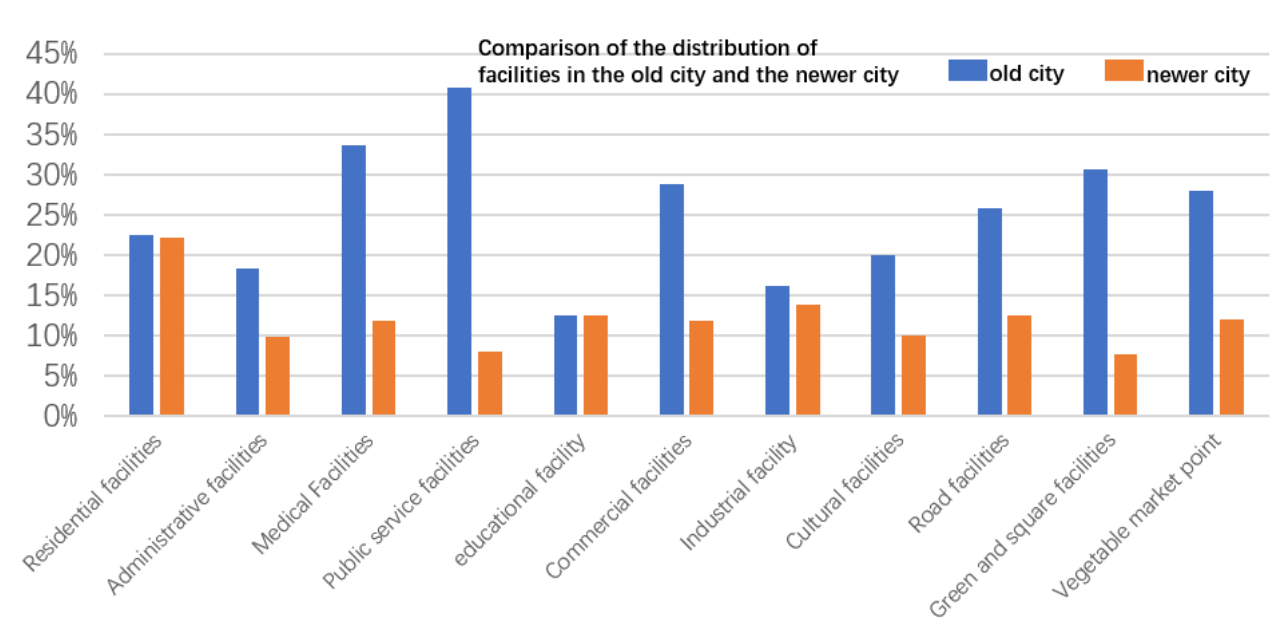

Figure 6.Comparison of the number of facilities in the old city and the newer city in the number of facilities in the entire town.Source: Self-painted.

\subsubsection{The delimitation of living units under the current block form}

Conceptually delineate the living units in the current old city and newer city.Due to the small size of the old city block,the population structure is dominated by the elderly, and the distribution of facilities is mostly around the county center.There are many types of facilities,but the quality is not high.The road scale in the old city is about $200 \mathrm{~m}$. The current green space is expanded from the existing natural resources and ancient relics. The public service facilities are mostly located in the center of the city. The school land is relatively distributed.dispersion. The newer urban area has a larger block scale,the population structure is dominated by young people,the distribution of facilities is mostly set around roads, and the types of facilities need to be supplemented.The road scale of the newer urban area is about $300 \mathrm{~m}$. The current public service facilities are mostly arranged along horizontal and vertical roads, the current green space is outside the urban area,and the school layout is mostly scattered,as shown in Figure 7 below.

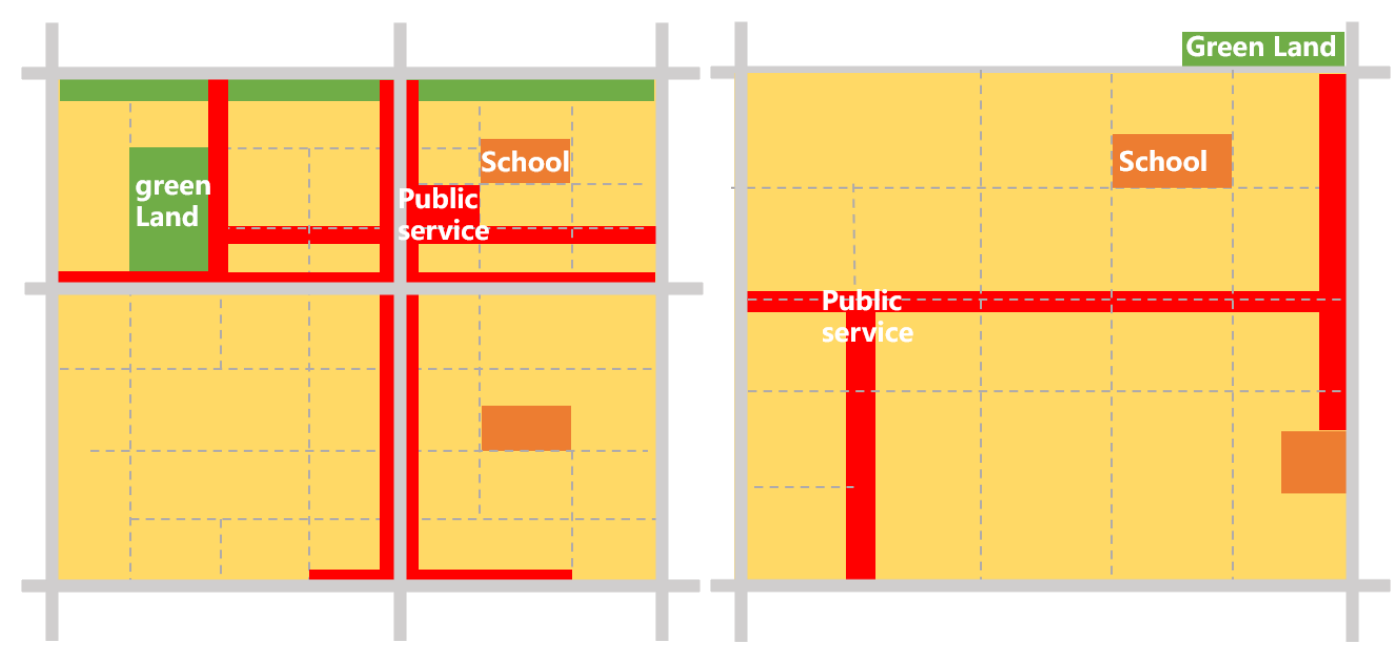

Figure 7.Conceptual diagram of the current living units in the old and newer urban areas.Source: Self-painted.

\subsubsection{The current situation of space in different block forms}

Through the collection and arrangement of the current space in the two urban areas of Quyang,the main problems are concentrated in the four aspects of road traffic,public service facilities,open space and cultural facilities.Among them,the current road traffic in the old city is chaotic,the current situation of mixed traffic between people and vehicles is serious, the overall quality of public services is not high,the 
open space is fragmented and relatively lacking, and cultural facilities are relatively lacking,as shown in Figure 8.

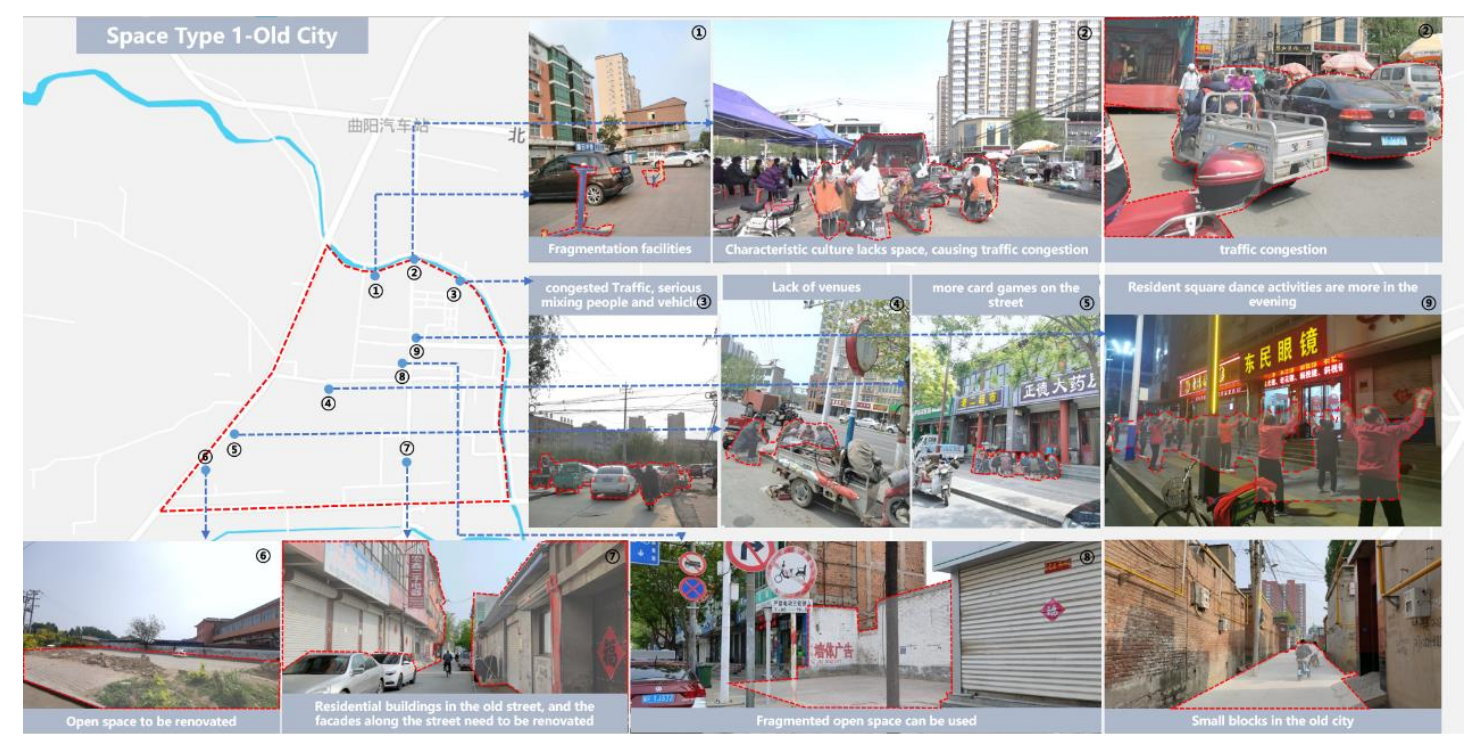

Figure 8.The current situation of residents' space in the old city.Source: Self-painted.

Newer urban areas lack reasonable road traffic planning,slow-moving systems have not been established,infrastructure is relatively lacking, and activity space is relatively lacking,as shown in Figure 9.

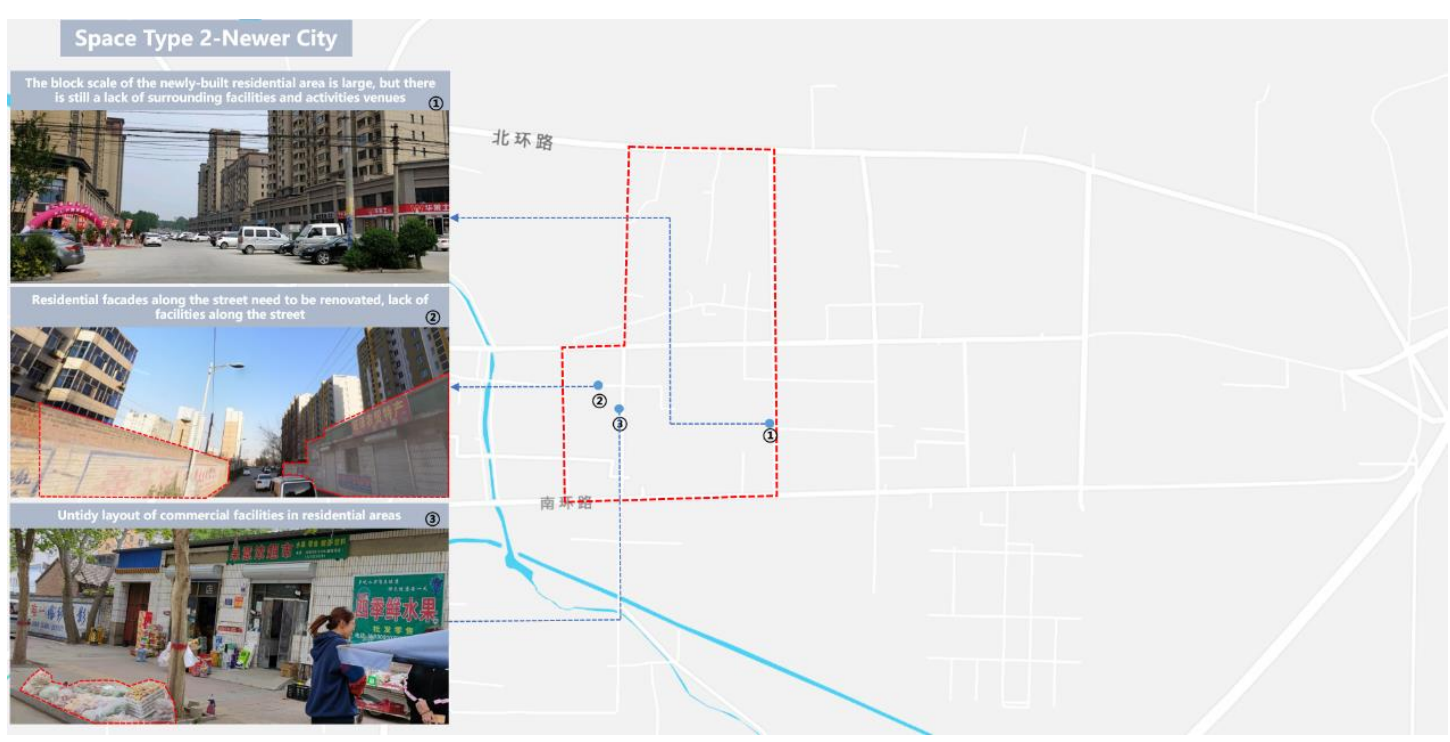

Figure 9.The current situation of space in newer urban areas.Source: Self-painted.

\subsection{Resident behavior characteristics and demand analysis}

Through empirical investigations to study the current living characteristics and needs of residents in the old and newer urban areas of Quyang County, and to explore the difference between the current space supply and residents' demand, the author distributed questionnaires to the old and newer urban areas and collected a total of 196 questionnaires.In general,the behavior characteristics of the elderly (after 60 years old) and young people (26-40 years old) show different states.

\subsubsection{Analysis of Residents' Basic Behavior Characteristics in Different Space Forms}

By investigating the travel trajectory of residents at the same time on weekdays and weekends,superimposing the current facilities and resident heat maps,selecting typical activities venues 
for residents in different time periods, and summarizing the basic travel characteristics of residents in different spatial forms In general,the vitality of the residents in the old city is higher,and the vitality of the residents in the new city is weaker, as shown in Figure 10, which specifically shows as follows:

First, the elderly in the old city will have more frequent daily activities, and they are also the main users of the facilities and public spaces in the old city. Whether on weekdays or weekends, the surrounding areas of Yihuiyou Shopping Center in the old city are highly concentrated, and are in a state of high heat value at different times throughout the day.

The second is that young people in newer urban areas will have fewer daily activities.In newer urban areas, weekend activities are stronger than weekday activities,morning and evening.The time period is stronger than the activity value at noon and afternoon.

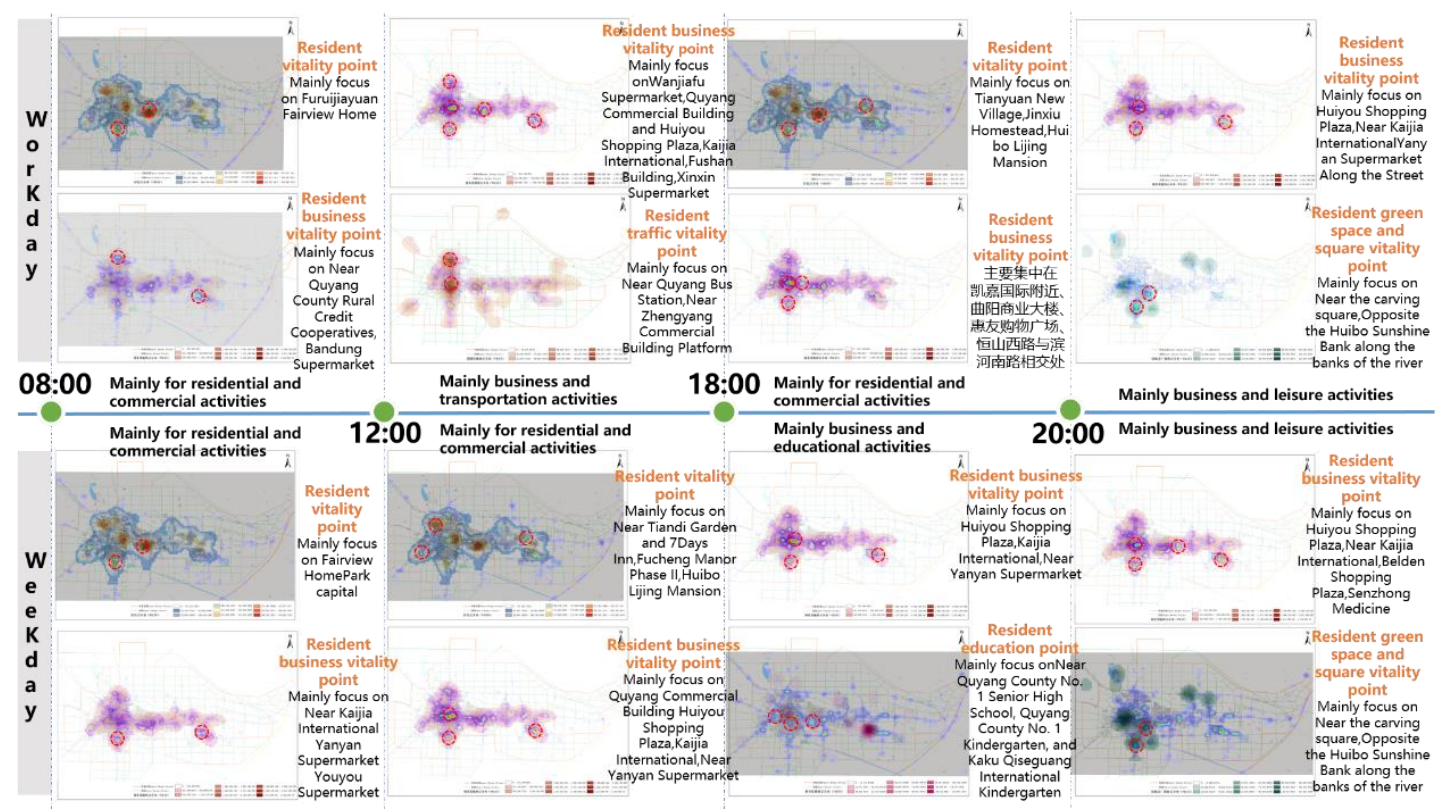

Figure 10.Resident behavior trajectory graph.Source: Self-painted.

\subsubsection{Analysis on the Use Characteristics and Demands of Public Service Facilities and}

\section{Leisure Space}

Public service facilities and recreational spaces are important spatial elements to improve the living standards of residents.According to the survey,different groups also have differences in the types of facilities and activities used by different groups,as shown in Figure 11, which is specifically reflected in:

The first is that the elderly in the old city have a relatively high demand for infrastructure and leisure space, and the activities are mainly concentrated in the daytime.Among them, the most frequent use of facilities for the elderly over 60 years old is Da Nanguan. The basic living facilities dominated by the vegetable market,the green leisure space along the Mengliang River,and the leisure cultural space dominated by cultural performances.In addition, according to the survey, due to the relatively small scale of the old city block,the current way of travel for the elderly is step by step.Behavioural,the demand for activity types is mainly manifested in healthy travel and leisure and entertainment activities.

Second, in the newer urban areas,young people as the main group have a great demand for infrastructure,leisure space, and improved public service facilities.Since young people's main activities are mostly in the morning on weekdays, after get off work and weekends, the frequency of use of the current facilities is The higher ones are mainly basic education and living facilities such as elementary schools and Bandung Supermarkets.Since there is less leisure and entertainment space in the newer urban areas,from 
the perspective of future demand,there are The demand will be high.In addition,according to the survey, due to the larger block size of the newer urban area,the current mode of travel for young people is mainly cycling and car behavior, and their demand for activity types is mainly manifested in healthy travel and social interaction activities.

\begin{tabular}{|c|c|c|c|c|c|}
\hline \multicolumn{6}{|c|}{ Behavior characteristics of residents in the old city } \\
\hline $\begin{array}{c}\text { Main } \\
\text { activity } \\
\text { crowd }\end{array}$ & $\begin{array}{c}\text { Travel } \\
\text { mode }\end{array}$ & $\begin{array}{c}\text { Main event } \\
\text { destination }\end{array}$ & $\begin{array}{c}\text { Average } \\
\text { activity } \\
\text { block size }\end{array}$ & type of activity & $\begin{array}{c}\text { Time period } \\
\text { when the } \\
\text { activity occurs }\end{array}$ \\
\hline elder & walking & $\begin{array}{c}\text { Surrounding green } \\
\text { areas, cultural } \\
\text { performance venues, } \\
\text { vegetable markets }\end{array}$ & $\begin{array}{c}\text { Around } \\
200 \mathrm{~m}\end{array}$ & $\begin{array}{c}\text { travel activities } \\
\text { Leisure and } \\
\text { entertainment } \\
\text { activities }\end{array}$ & Daytime \\
\hline
\end{tabular}

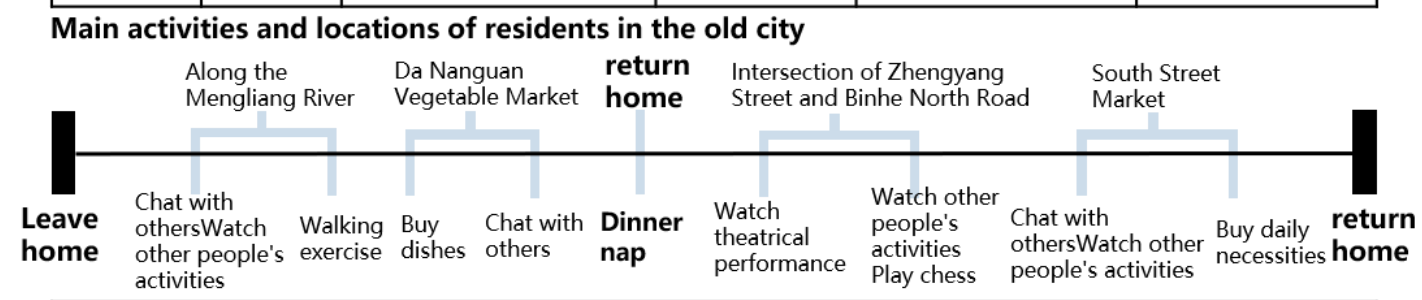

\begin{tabular}{|c|c|c|c|c|c|}
\hline \multicolumn{6}{|c|}{ Behavioral characteristics of residents in newer urban areas } \\
\hline $\begin{array}{c}\text { Main } \\
\text { activity } \\
\text { crowd }\end{array}$ & $\begin{array}{c}\text { Travel } \\
\text { mode }\end{array}$ & $\begin{array}{c}\text { Main event } \\
\text { destination }\end{array}$ & $\begin{array}{c}\text { Average } \\
\text { activity } \\
\text { block size }\end{array}$ & type of activity & $\begin{array}{c}\text { Time period } \\
\text { when the } \\
\text { activity occurs }\end{array}$ \\
\hline $\begin{array}{c}\text { young } \\
\text { people }\end{array}$ & $\begin{array}{c}\text { Cycling } \\
\text { drive }\end{array}$ & $\begin{array}{c}\text { School,workplaces } \\
\text { upermarket }\end{array}$ & $\begin{array}{c}\text { Around } \\
300 \mathrm{~m}\end{array}$ & $\begin{array}{c}\text { Travel activities } \\
\text { Social interaction }\end{array}$ & $\begin{array}{c}\text { Morning and } \\
\text { evening on } \\
\text { weekdays }\end{array}$ \\
\hline
\end{tabular}

Main activities and locations of residents in newer urban areas

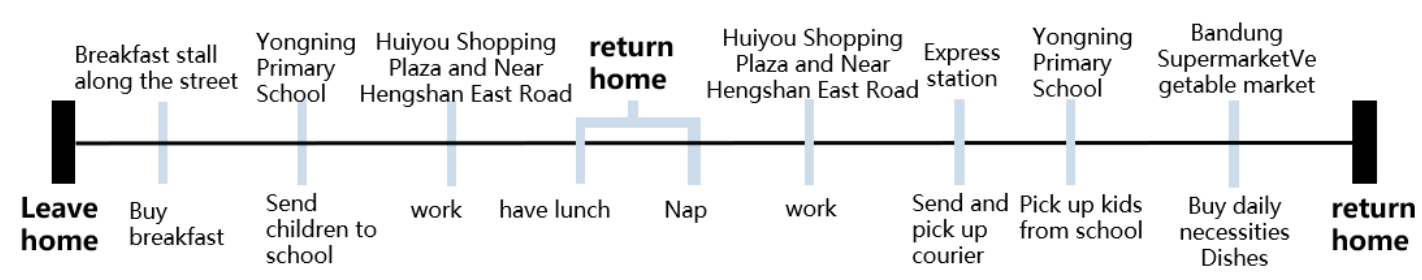

Figure 11.Residents' behavioral characteristics in different spatial forms.Source: Self-painted.

\subsubsection{Resident travel characteristics and demand analysis}

According to the survey,residents have a high willingness to travel on foot,but the actual proportion of walking trips is still relatively low.According to the questionnaire of residents' demand for neighborhoods,residents' needs for travel are also different in different block sizes under different spatial forms.The specific performance is as follows :

First,the residents of the old city living after 60 years old have higher requirements for the walking environment.Due to the relatively complete facilities and the rich natural landscape in the old city,as shown in Figure 12,although the old people's daily travel is mainly on foot,from the future In terms of demand, the elderly expect to be able to combine the walking environment with the landscape,followed by greater demand for related cultural facilities and park space in the old city. 


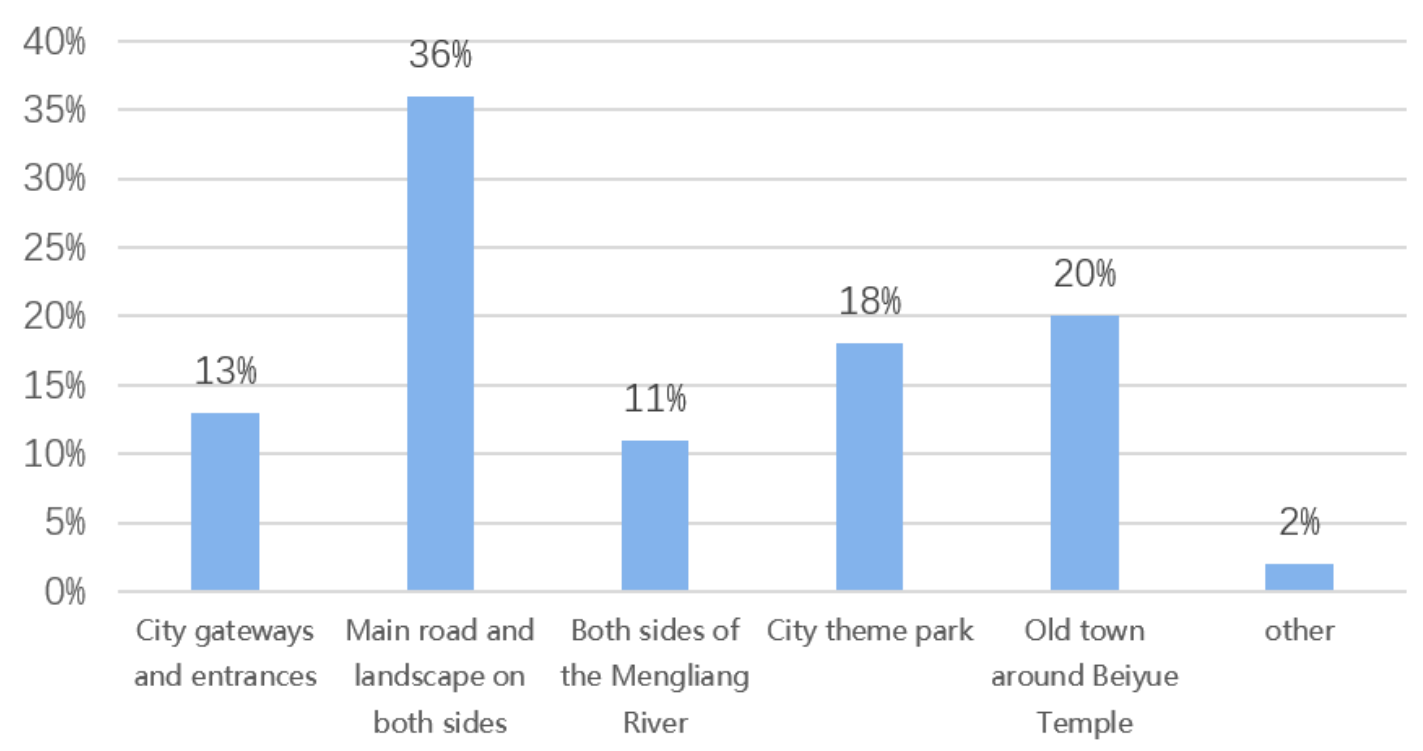

Figure 12.Statistics of residents' demand for neighborhoods in the old city.Source: Self-painted.

Second, residents in the newer urban areas of 26-40 years of life have higher requirements for the accessibility and convenient connectivity between destinations.14\% of the residents said they would increase the accessibility by foot, but $31 \%$ of the residents said Need to add non-motorized lanes, as shown in Figure 13.Due to the large block size in the urban area,residents often use cycling and car travel.The relative imperfection of facilities has also caused residents in newer urban areas to pay attention to the convenience between destinations.According to statistics, $22 \%$ of residents expressed the need to enrich the facilities in the neighborhood, and $21 \%$ of the residents expressed the need to increase green space.In addition to the requirements for convenience between destinations, there is a concentration of facilities that are more related to the needs of residents in newer urban areas.In basic living facilities and public spaces.

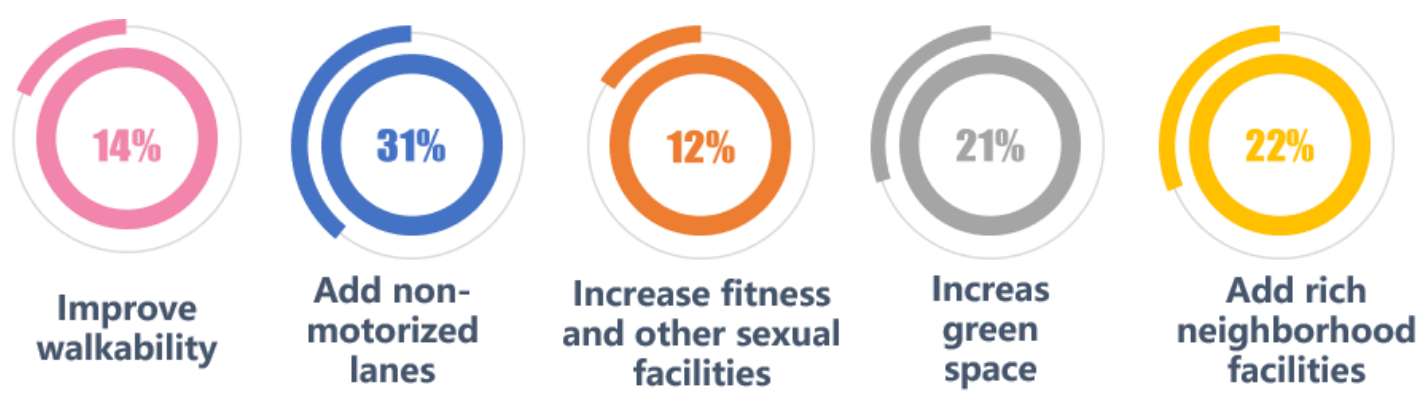

Figure 13.Statistics of neighbourhood demand in newer urban areas.Source: Self-painted.

\subsection{A summary of the problems of current space supply and resident differentiation}

\subsubsection{Urban travel is dominated by cars, and residents' health and slow-moving needs are}

\section{difficult to meet}

At present,the elderly residents living in the old city have a relatively high actual walking rate,but under the vehicle-based transportation mode,they have higher requirements for the walking environment.At the same time, with the increase in health awareness, people's demand for leisure walking is also With the continuous increase, the young people aged 26-40 in the newer urban areas emphasize the speed of commuting, and the actual walking ratio has been greatly reduced,and they are paying more attention to the convenience between destinations. 


\subsubsection{The configuration of urban facilities is simplistic,and the residents' health and}

\section{spiritual needs are difficult to meet}

With the complexity of the population structure of different urban areas,the demand characteristics formed by groups of different ages and different economic levels tend to be differentiated for different urban areas.The old urban area is based on the existing facilities and is more culturally relevant.The spiritual needs are increasing,so the demand for upgraded facilities will increase.Newer urban areas need to meet the basic facilities construction on the basis of existing facilities that are not perfect.Therefore,the future new urban areas will not only improve the facilities On the basis of improving the facilities, it is necessary to upgrade the facility configuration.

\subsubsection{Lack of leisure and cultural space in cities and towns, and it is difficult to meet the}

\section{needs of residents for neighbourhood communication}

Leisure cultural space is an important space carrier for the interaction of residents.For residents in the old city with the elderly as a group,there are relatively more face-to-face group life and neighborhood communication,but it is difficult to realize a cultural and leisure space that is developed separately. From the perspective of space scale, the new urban area has a larger block size,and the sense of the boundary of the neighborhood reduces the fun of walking in the neighborhood. From the perspective of public space, the current newer urban area is an unattractive leisure space.

\section{Research on the Renewal Strategy of Residents'15-Minute' Healthy cities Guided by the Block Shape}

\subsection{The construction of a healthy skeleton that meets the needs of residents for healthy}

\section{travel in different block patterns}

In the 15-minute living circle,the road serves as the skeleton of a healthy living unit,supporting residents' daily travel activities. The block scale of the old city is small, and the residents travel mainly on foot.The demand for slow walking trails is greater.Compared with the block scale of the new city block,the residents are mainly riding,but the accessibility between the newly built roads is not high,so it is satisfying On the basis of the travel needs of residents at different block sizes, the internal slow traffic system design of the unit is strengthened to keep the traffic lanes smooth and achieve chronic access, pay attention to the establishment of greenways to meet the needs of residents for healthy travel,and at the same time,Separate the pedestrian greenway design from the roadway,to encourage people and vehicles to branch, and to promote healthy travel among residents.

\subsection{A healthy patch bearing that satisfies the healthy social exchanges of residents in}

\section{different neighborhoods}

In the 15-minute cities, public service facilities serve as patches of a healthy living unit, which bears the needs of residents for daily communication. Residents in the old city are mainly elderly people who have greater demand for local cultural output.Residents in newer city areas are mainly young people. They have a higher demand for basic public service facilities and educational facilities. Therefore,they can meet the needs of different age groups in different neighborhoods. On the basis of demand,focus on improving the configuration of public service facilities in the unit,combining the unit center and main roads for a reasonable layout, and planning the layout of the neighborhood center in the unit, and arranging education facilities around the neighborhood center to improve community public service facilities services In addition, in response to the fact that public service resources are relatively scarce under the epidemic,the 
facilities are divided into daily use and use under emergency disaster conditions,and the neighborhood center will be used as a supply center for resources provided in emergency disasters.

\subsection{Meet the healthy substrate guidance of residents' healthy leisure activities in different}

\section{block patterns}

Within the 15-minute cities,green spaces and public spaces serve as the matrix of healthy living units,guiding the mental health of residents to a certain extent.Residents in the old city are affected by the fragmentation of the current open space and the low utilization rate.They lack places for residents' daily leisure and entertainment.Residents in the newer city have less leisure activities and lack of places for exercise and recreation.Most of them stay at home after get off work.Residents' leisure activity needs cannot be met.Therefore, to meet the needs of residents for leisure activities in different block forms, the unit first focuses on the design of internal green space and open space,and establishes community parks around the neighborhood center,combined with community parks to set up cultural squares and other facilities to provide places for local opera performances, while paying attention to the community The combination of epidemic prevention and disease prevention in the park meets the needs of residents for daily leisure activities.It also serves as an emergency shelter during the epidemic period,emphasizing the diversity and integration of community parks, as shown in Figure 14.

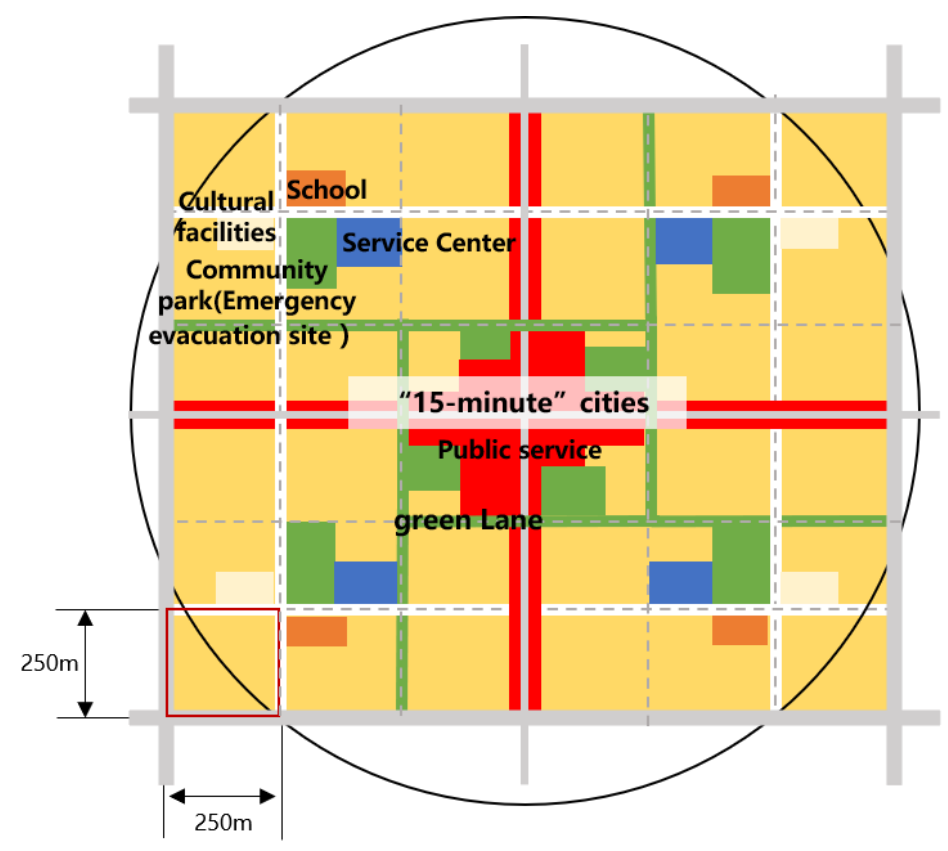

Figure 14.Conceptual model diagram of new urban living unit.Source: Self-painted.

\section{References}

[1] You,Z.X.(2019).study on the renewal and reconstruction of old areas based on the concept of healthy city -- Taking the land renewal and reconstruction of Jinzhou Municipal People's Congress as an example.Chongqing: China Urban Planning Society.

[2] Xiao,Z.P.Chai,Y.W.and Zhang,Y.(2014).'Review on the progress of life circle planning research and planning practice at home and abroad,' planner,30(10),pp.89-95.

[3] Abdel-Hadi,A.,El-Nachar,E.,and Safieldin,H.(2011).'Residents' Perception of Home Range in Cairo,' Open House International,36(2),pp.59-69. 
[4] Li,M.(2017).'research on the planning countermeasures of "15 minute community life circle" based on the characteristics of residents' behavioral needs,' Journal of urban planning,1,pp.111-118.

[5] Chen,L.Y.(1989).'life circle, metropolitan area and urban system, ' economic outlook,(16),pp.127-128

[6] Gu,L.S.(2003).'Characteristics and new trends of foreign land planning,' World geographic research,12(1),pp.60-70.

[7] Lin Ziyu (1984).'discussion on the planning and implementation of local life circle,' URBAN AND PLANNING,(11),pp.175-187.

[8] Zhu,Y.R.(2009).'the development of residential planning in Korea and its enlightenment,' International Urban Planning,(5),106-110.

[9] Teng,J.Z.(1985).'A review of the low commuting rate in the central cities of the Metropolitan Area -changes in daily life and correlation mechanism,' Department of education,Kyoto University (Humanities),(31),pp.141-143.

[10] Yamashita,K.(1970).'the life circle of dachundu and rikuzentakata in Iwate County,' Northeast geography,(1),pp.6-11.

[11] Shannon,R.Mant,J.Dessewffy,M.and Harrison,L.(2019).'20-minute neighbourhoods: Creating a more liveable Melbourne,' Journal of Transport \& Health,14,pp.100773.

[12] Secretary, NSW Health.Public Health Emergency Response Preparedness Minimum Standards[online]. Available at:https://www1.health.nsw.gov.au/pds/ActivePDSDocuments/PD2019_007.pdf,2020-3.[Access ed at 16 September 2021]

[13] Chen, Q.H.and Xu,P.W.(1987).'preliminary study on the evaluation method of urban living environment quality, ' Urban Planning,(5),pp.52-58.

[14] Yuan,J.D.Sun,Z.J.Zhang,N.and Zhao,Z.(2005),"reconstruction of China's urban regional system based on" daily life circle ",Geosciences,25(1),pp.17-22.

[15] Sun,D.S.Chai,Y.W.and Zhang,Y.(2016).'definition and measurement of community life circle: Taking Qinghe area of Beijing as an example,' Urban Development Research,23 (9),pp.1-9.

[16] Xiong,W.and Xu,Y.L.(2010).'research on urban residential environment from the perspective of public facilities -- Taking Nanjing as an example,' Modern Urban Research,(12),pp.35-42.

[17] Kang,X.J.(2020).'optimization of urban and rural public service facilities allocation based on small town life circle -- a case study of Wafangdian City,Liaoning Province,' Small Town Construction,38(5),pp.92-100.

[18] Sun,D.S.Chai,Y.W.and Zhang,Y.(2016).'definition and measurement of community life circle: Taking Qinghe area of Beijing as an example,' Urban Development Research,23 (9),pp.1-9.

[19] Zhu,C.S.Wang,D.and Ma,L.(2010).Study on the allocation of urban and rural public service facilities based on life circle -- Taking Xiantao as an example.Chongqing: China Urban Planning Society,Chongqing Municipal People's government.

[20]Wang,L.Li,X.T.and Yang,X.M.(2020).'integrating health into 15 minute community life circle: community response under public health emergencies,' Planner,36(6),pp.102-106. 